\title{
Libertarian Anarchism Is Apodictically Correct
}

\author{
James Redford*
}

December 15, 2011

\begin{abstract}
Aвstract: It is shown that libertarian anarchism (i.e., consistent liberalism) is unavoidably true.
\end{abstract}

\section{Schemata of Property-Allocation Rights}

Homesteading is the only logical answer to who has the better claim on a previously unused resource. It answers that the first user does, since the first user is the one who took it from a de facto state of non-ownership to a de facto state of ownership (i.e., in the sense of physical use by a sapient being). All the homesteading principle does is state that how property is in actual reality brought into de facto ownership is also rightful.

All other allocations of rights to ownership are illogical because they violate how resources are actually brought into use. That is, they violate the very nature of mankind's relation to physical reality.

For example, let us consider a socialist allocation of rights. In this case, everyone has an equal rightful share of all property brought into de facto ownership (including the property of everyone's person). But then, nothing could have been rightfully brought into use in the first place, as that would require permission to do so from every other person. Even if we set a majority voting rule, no such voting can rightfully take place as it requires standing room and the usage of people's bodies, yet where did rightful permission come to use them? Based upon such an allocation of property rights, it could have never come about.

The other option is a monarchic (or oligarchic) allocation of property rights. In this case, one person (or particular group of people) rightfully own all de facto property (including the property in every person's body). Yet how did such ruler(s) come to

*Email address: <jrredford@yahoo.com>. 
have this right which no one else has? If one says via might making right, via voting, via greater intelligence, or via anything else, then one is presupposing a prior, more fundamental allocation of property rights (since in order to exist, people necessarily would have been making use of property before this ruling class obtained this position, and if such use wasn't rightful then mankind's very existence isn't rightful).

The above are all the logically available options for allocation of rightful ownership. Any other conceivable schemata will simply be mixtures of two or more of the above three, and hence necessarily suffer from the same logical problems of one or both of the latter two.

Furthermore, regarding rightful self-ownership and the homesteading principle:

1.) One cannot deny the principle of rightful self-ownership without committing a performative contradiction. For one must, at the very least, presuppose one's own rightful self-ownership in order to be able to argue against the principle. As it may well be asked: How can one give such an argument if one does not even believe oneself to be the sole rightful owner of one's very own body (and vocal chords)? Thus, it is for this reason that the principle of rightful self-ownership rises to the level of an inescapable axiom: i.e., that which cannot be denied without necessitating its use in the denial. Thus also, it could never be argued that argument is impossible without thereby committing a performative contradiction. As well, this logically means that the principle of rightful self-ownership is only valid as a per se universal human principle. For A cannot coherently argue that only he is a proper natural self-owner whereas others are not. For then B could "steal" A's argument and use it against him-i.e., if it is valid for A then it must be valid for B as well. For as Abraham Lincoln pointed out (if only it had been that Lincoln himself had bothered to follow the logic of his below argument!): 1

If A can prove, however conclusively, that he may of right enslave B, why may not $B$ snatch the same argument and prove equally that he may enslave A? You say A is white and B is black. It is color, then; the lighter having the right to enslave the darker? Take care. By this rule you are to be slave to the first man you meet with a fairer skin than your own. You do not mean color exactly? You mean the whites are intellectually the superiors of the blacks, and therefore have the right to enslave them? Take care again. By this rule you are to be slave to the first man you meet with an intellect superior to your own. But, say you, it is a question of interest, and if you make it your interest you have the right to enslave another. Very well. And if he can make it his interest he has the right to enslave you.

\footnotetext{
${ }^{1}$ Abraham Lincoln, "Fragment. On Slavery [July 1, 1854?]" in John G. Nicolay and John Hay (editors), Complete Works of Abraham Lincoln, Volume II (New York: Francis D. Tandy Company, New and Enlarged Edition, 1905; original ed., 1894), p. 186.
} 
In addition we would not then have a universal ethic for mankind as such, but instead an arbitrary ethic-i.e., we would have to posit an unnecessary and arbitrary additional ethical rationale as to why rightful self-ownership is not universalizable, and would thus be violating Ockham's Razor.

It is for this reason and others that the libertarian concept of self-ownership is apodictically true. Nor, it should be mentioned in passing, does it derive an "ought" from an "is"-rather, it derives an "ought" from an "ought": an "ought" everyone must necessarily presuppose in order to even begin to deny it.

2.) This same logical principle also applies to external property (i.e., external from one's body). Since all virgin land had to be at some point homesteaded by a first user, one cannot coherently argue against the properness of this principle for then the human race could not even exist (and hence the arguer could not even exist). Thus, to argue against the homesteading principle would be to necessarily argue against one's own existence, but the very act of arguing presupposes one's own right to argue and hence right to exist (as one cannot argue without existing). Thus, one arguing against the homesteading principle would be committing a performative contradiction.

It is for this reason and others that the libertarian concept of rightful ownership of homesteaded resources is also apodictically true. Nor, it should also be mentioned in passing, does it derive an "ought" from an "is"-rather, it derives an "ought" from an "ought": an "ought" everyone must necessarily presuppose in order to even begin to deny it.

\section{深}

The right of a nonaggressor to control the property of their own person and to control external property obtained via homesteading implies the libertarian Nonaggression Principle: that no person or group of people may initiate the use of force against another or their justly-acquired property, or threaten to initiate the use of force against another or their justly-acquired property.

Ultimately all just property titles can (1) be traced back by way of voluntary transactions to the homesteading of unused resources (which would thus be consistent with being able to do what one wishes with one's own, including being able to transfer title to property); or (2) in the case in which such resources were expropriated from (or abandoned by) a just owner and the just owner or his heir(s) can no longer be identified or are deceased, where the first nonaggressor possesses the resource (which can then be considered another form of homesteading). 
For more on the above, see the following:

1. Chapter 8: "Interpersonal Relations: Ownership and Aggression", and also pp. xvi-xvii (paragraphs 14-18) of the introduction by Prof. Hans-Hermann Hoppe in the new edition of Prof. Murray N. Rothbard's The Ethics of Liberty (New York, N.Y.: New York University Press, 1998; originally published 1982) <http://mises.org/pdf/esam.pdf $>$, $<$ http://webcitation.org/5ve4G0915 $>$.

2. The section entitled "Property Rights" in Chapter 2: "Property and Exchange" of Prof. Rothbard's For a New Liberty: The Libertarian Manifesto (New York, N.Y.: Collier Books, second edition, 1978; originally published 1973) $<$ http://mises.org/rothbard/foranewlb. pdf $>,<$ http://webcitation.org/62wec1LoP $>$.

See also the below two articles, paying particular attention to the Estoppel in the first article:

3. N. Stephan Kinsella, "New Rationalist Directions in Libertarian Rights Theory", Journal of Libertarian Studies, Vol. 12, No. 2 (Fall 1996), pp. 313-326 <http://mises.org/ journals/js/12_2/12_2_5.pdf>, <http://webcitation.org/62wjlptwo $>$.

4. N. Stephan Kinsella, "Punishment and Proportionality: the Estoppel Approach", Journal of Libertarian Studies, Vol. 12, No. 1 (Spring 1996), pp. 51-73 <http://mises.org/ journals/js/12_1/12_1_3.pdf $>,<$ http://webcitation.org/62wjX9D6r $>$.

\section{The Impossibility of a Nonaggressing Government}

It is demonstrably provable that governments cannot exist without initiating force: for a government inherently can only exist by initiating force-a government ceases to exist when it ceases initiating force. Those who support the prohibition on initiation of force, such as libertarians and Objectivists, and yet who also advocate government, put themselves in a position which is self-contradicting and impossible to solve.

As a government (i.e., a state), by definition, must involve one or both of the following (historically speaking, almost always both):

1. A coercive tax levy.

2. A generally successful coercive regional monopoly over ultimate control of the law (i.e., on the courts and police, etc.). This is a feature of all governments. 
Both of which initiate force. And if it does not involve either of those, then quite simply, it is not a government. Thus, those who hold the nonaggression principle (i.e., Objectivists and libertarians) and yet who also advocate government (even "minimal" government) find themselves in an insoluble contradiction.

As far as No. 1, this can be gotten around by simply maintaining that enough people would just give their money to the government-unlikely as the possibility of that is.

But No. 2 is insoluble. For example, if a business were to arrange their own defense and court services without initiating force, and the government were to use force to stop them, then, by definition, the government would be initiating force. Q.E.D. If the government does not stop them, then it would cease being a government: for no longer would it have a monopoly over control of the law-but instead, it would just be another private protection agency. There is no way around this: either the government initiates force against the business, thereby maintaining its monopoly over control of the law, and hence its status as government-or the government refrains from initiating force against the business, thereby losing its monopoly over control of the law, and hence losing its status as government, to become instead just another private protection agency.

The above argument shows that there can be no such thing as a government which does not initiate force. And thus also, nonaggression unavoidably results in anarchy.

涾

For more on the above, see the below article:

- Roy Alan Childs, Jr., "An Open Letter to Ayn Rand: Objectivism and the State", sent to Rand on July 4, 1969, published in The Rational Individualist (Society for Rational Individualism), Vol. 1, No. 10 (August 1969), pp. 4-12<http://isil.org/ayn-rand/childsopen-letter.html $>$, <http://webcitation.org/62wfS2Wt8 $>$. Republished in Joan Kennedy Taylor (editor), foreword by Thomas Szasz, Liberty Against Power: Essays by Roy A. Childs, Jr. (San Francisco, Cal.: Fox \& Wilkes, 1994), pp. 145-156.

\section{The Anarchism of Jesus Christ}

See also my following article on the logically unavoidable anarchism of Jesus Christ's teachings. It is logically complete on this subject, in the sense of its apodixis.

- James Redford, "Jesus Is an Anarchist", Social Science Research Network (SSRN), December 4, 2011 (originally published December 19, 2001) <http://ssrn.com/abstract= 1337761 >, <http://webcitation.org/63ialubsg >. 
Below is the abstract to my above article:

Aвstract: The teachings and actions of Jesus Christ (Yeshua Ha'Mashiach) and the apostles recorded in the New Testament are analyzed in regard to their ethical and political philosophy, with analysis of context vis-à-vis the Old Testament (Tanakh, or Hebrew Bible) being given. From this analysis, it is shown that Jesus is a libertarian anarchist, i.e., a consistent voluntaryist. The implications this has for the world are profound, and the ramifications of Jesus's anarchism to Christians' attitudes toward government (the state) and its actions are explicated.

In the form of the Golden Rule (see Matthew 7:12; Luke 6:31), Christ commanded humanity to follow an even higher standard than the libertarian law code. However, the Golden Rule is (in its interpersonal form ${ }^{2}$ ) a social ethic and not a legal ethic, and so unlike libertarianism cannot be enforced by a mortal law code. Rather, it is a standard that people are called to follow based upon their voluntary choice (as far as mortal law-enforcement mechanisms are concerned).

\section{Appendices}

\section{A Articles Everyone Should Be Familiar With}

1. Prof. Murray N. Rothbard, "The Anatomy of the State", Rampart Journal of Individualist Thought, Vol. 1, No. 2 (Summer 1965), pp. 1-24. Reprinted in a collection of some of Rothbard's articles, Egalitarianism As a Revolt Against Nature and Other Essays (Washington, D.C.: Libertarian Review Press, 1974) <http://mises.org/books/egalitarianism. pdf $>,<$ http://webcitation.org/5ve3r05ti $>$.

2. Prof. Murray N. Rothbard, "Defense Services on the Free Market", Chapter 1 from Power and Market: Government and the Economy (Kansas City: Sheed Andrews and McMeel, Inc., 1970), pp. 1-9 <http://web.archive.org/web/20050923192825/mises. org/rothbard/power\&market.pdf >, <http://webcitation.org/5ve3w5w9a > .

3. Prof. Hans-Hermann Hoppe, "The Private Production of Defense", Journal of Libertarian Studies, Vol. 14, No. 1 (Winter 1998-1999), pp. 27-52 <http://mises.org/journals/jls/ 14_1/14_1_2.pdf $>,\langle$ http://webcitation.org/5ve41VasQ $>$.

\footnotetext{
${ }^{2}$ As Christ also gave the Golden Rule as applying to one's thoughts about others (viz., Matthew $5: 22,28,29$; the "without a cause" proviso of some texts is not in the earliest manuscripts: see in particular the English Standard Version and the footnote to Matthew 5:22 in the New King James Version).
} 
4. Prof. Hans-Hermann Hoppe, "Fallacies of the Public Goods Theory and the Production of Security", Journal of Libertarian Studies, Vol. 9, No. 1 (Winter 1989), pp. 27-46<http:// mises.org/journals/jls/9_1/9_1_2.pdf $>,<$ http://webcitation.org/5ve485kNf $>$. Reprinted in Hans-Hermann Hoppe, The Economics and Ethics of Private Property: Studies in Political Economy and Philosophy (Auburn, Ala. Ludwig von Mises Institute, 2nd ed., 2006; 1st ed., 1993), pp. 3-32 <http://mises.org/books/economicsethics.pdf $>,<$ http: //webcitation.org/63rPtxUq7>.

5. Prof. Frank J. Tipler, "The structure of the world from pure numbers", Reports on Progress in Physics, Vol. 68, No. 4 (April 2005), pp. 897-964, doi:10.1088/0034-4885/68/ 4/R04 <http://math.tulane.edu/ tipler/theoryofeverything.pdf $>$, <http://webcitation. org/5nx3CxKm0>. Also released as "Feynman-Weinberg Quantum Gravity and the Extended Standard Model as a Theory of Everything", arXiv:0704.3276, April 24, 2007 $<$ http://arxiv.org/abs/0704.3276>.

\section{B Basic A Priori Axioms}

Along with those given in Section 1 of this article, below are additional basic a priori axioms. That is, true synthetic a priori propositions; or, propositions which cannot be denied without necessitating their use in the denial.

1. I think, therefore I am. (Proof of the existential reality of one's own existence.)

If one did not exist in some form then one would not be able to even think "I do not exist."

2. Truth, and knowledge of truth, exists.

Whoever denies the existence of truth grants that truth does not exist. Yet, if truth does not exist, then the proposition "Truth does not exist" is true. And if there is anything true, then truth exists.

3. Conscious humans act. (Prof. Ludwig von Mises's Axiom of Action.)

It cannot be coherently denied that this proposition is true, since the denial would have to be categorized as an action. $3^{3}$

As well, there are logically necessary implications of this axiom:

\footnotetext{
${ }^{3}$ The text used in this axiom No. 3, and also axiom No. 4, comes largely from Prof. Hoppe's book cited below in this section: specifically, Chapter: "Praxeology and Economic Science", pp. 22-25, and Chapter: "On Praxeology and the Praxeological Foundation of Epistemology", Part 3, pp. 65-66, respectively.
} 
3. (a) With every action an actor pursues a goal; and whatever the goal may be, the fact that it is pursued by an actor reveals that he places a relatively higher value on it than on any other goal of action he could conceive of at the start of his action.

(b) In order to achieve his most highly valued goal an actor must interfere or decide not to interfere (which, of course, is also an interference) at an earlier point in time to produce some later result; such interferences invariably imply the employment of some scarce means (at least those of the actor's body, its standing room and the time absorbed by the interference).

(c) These means must also have value for an actor-a value derived from that of the goal-because the actor must regard their employment as necessary in order to effectively achieve the goal; and actions can only be performed sequentially, always involving the making of a choice, i.e., taking up that one course of action which at some given point in time promises the most highly valued result to the actor and excluding at the same time the pursuit of other, less highly valued goals.

(d) As a consequence of having to choose and give preference to one goal over another-of not being able to realize all goals simultaneously-each and every action implies the incurrence of costs. For example, forsaking the value attached to the most highly valued alternative goal that cannot be realized or whose realization must be deferred because the means necessary to effect it are bound up in the production of another, even more highly valued goal.

(e) At its starting point every goal of action must be considered worth more to the actor than its cost and capable of yielding a profit, i.e., a result whose value is ranked higher than that of the foregone opportunities. And yet, every action is also invariably threatened by the possibility of a loss if an actor finds, in retrospect, that the result actually achieved-contrary to previous expectations-has a lower value than the relinquished alternative would have had.

All of these categories-values, ends, means, choice, preference, cost, profit and loss, as well as time and causality-are implied in the axiom of action. The attempt to disprove the action-axiom would itself be an action aimed at a goal, requiring means, excluding other courses of action, incurring costs, subjecting the actor to the possibility of achieving or not achieving the desired goal and so leading to a profit or a loss. Thus, it is manifestly impossible to ever falsify the validity of Prof. Mises's axiom of action. As a matter of fact, a situation in which these categories of action would cease to have a real existence could itself never be observed, for making an observation, too, is an action.

4. Sapient humans are capable of argumentation and hence know the meaning of truth and validity. The so-called "A Priori of Argumentation". (This axiom relates strongly to axioms No. 2 and 3 ) 
It is impossible to coherently deny that one can argue, as the very denial would itself be an argument. In fact, one could not even silently say to oneself "I cannot argue" without thereby contradicting oneself. One cannot coherently argue that one cannot argue. Nor can one coherently dispute knowing what it means to make a truth or validity claim without implicitly claiming the negation of this proposition to be true (see axiom No. 2).

淡

For more on the above, see the following works:

1. Prof. Hans-Hermann Hoppe, Economic Science and the Austrian Method (Auburn, Ala.: Ludwig von Mises Institute, 2007; originally published 1995) <http://mises.org/books/ esam.pdf $>$, <http://webcitation.org/63rQDYtj2 >.

2. René Descartes, Discourse on the Method of Rightly Conducting the Reason and Seeking for Truth in the Sciences, Part 4, p. 101 in Elizabeth S. Haldane and G[eorge]. R. T. Ross (translators), The Philosophical Works of Descartes (Cambridge, U.K.: Cambridge University Press, 1911), Vol. 1 of $2<$ http://archive.org/details/philosophicalwor 01desc >, <http://webcitation.org/63rYLFB5m> (Vol. 1); <http://archive.org/details/ philosophicalwor02descuoft >, <http://webcitation.org/63rYNaLr2> (Vol. 2).

3. Thomas Aquinas, Summa theologiæ, First Part, Question 2, Article 1, Objection 3; English translation: Laurence Shapcote of the Fathers of the English Dominican Province, revised by Daniel J. Sullivan, The Summa Theologica, Vols. 17-18 of Mortimer J. Adler, Clifton Fadiman and Philip W. Goetz (editors), Great Books of the Western World (Chicago, Ill.: Encyclopædia Britannica, Inc., 2nd ed., 1990), 60 vols.

\section{Biography of the Author}

Born in Austin, Texas and raised in the Leander, Texas hill country, James Redford is a born-again Christian who was converted from atheism by a direct revelation from Jesus Christ. He is a scientific rationalist who concludes that the Omega Point (i.e., the physicists' technical term for God) and the Feynman-DeWitt-Weinberg quantum gravity/Standard Model Theory of Everything (TOE) is an unavoidable result of the known laws of physics. His website is the following:

- Theophysics: God Is the Ultimate Physicist < http://theophysics.chimehost.net $>,<$ http: //theophysics.host56.com>, <http://theophysics.ifastnet.com $>$. 